\title{
Ba incorporation in benthic foraminifera
}

\author{
Lennart J. de Nooijer ${ }^{1}$, Anieke Brombacher ${ }^{2, a}$, Antje Mewes ${ }^{3}$, Gerald Langer ${ }^{4}$, Gernot Nehrke ${ }^{3}$, Jelle Bijma ${ }^{3}$, and \\ Gert-Jan Reichart $^{1,2}$ \\ ${ }^{1}$ Dept. of Ocean Sciences, Royal Netherlands Institute of Sea Research, Landsdiep 4, 1797 SZ 't Horntje, the Netherlands \\ ${ }^{2}$ Faculty of Geosciences, Utrecht University, Budapestlaan 4, 3584 CD Utrecht, the Netherlands \\ ${ }^{3}$ Biogeosciences section, Alfred-Wegener-Institut Helmholtz-Zentrum für Polar- und Meeresforschung, \\ Am Handelshafen 12, 27570 Bremerhaven, Germany \\ ${ }^{4}$ The Laboratory, The Marine Biological Association of the United Kingdom, Citadel Hill, Plymouth, Devon, PL1 2PB, UK \\ ${ }^{a}$ now at: National Oceanography Centre, University of Southampton, Waterfront Campus, European Way, \\ Southampton SO14 3ZH, UK
}

Correspondence to: Lennart J. de Nooijer (ldenooijer@nioz.nl)

Received: 13 February 2017 - Discussion started: 28 February 2017

Revised: 12 June 2017 - Accepted: 21 June 2017 - Published: 19 July 2017

\begin{abstract}
Barium (Ba) incorporated in the calcite of many foraminiferal species is proportional to the concentration of $\mathrm{Ba}$ in seawater. Since the open ocean concentration of $\mathrm{Ba}$ closely follows seawater alkalinity, foraminiferal $\mathrm{Ba} / \mathrm{Ca}$ can be used to reconstruct the latter. Alternatively, $\mathrm{Ba} / \mathrm{Ca}$ from foraminiferal shells can also be used to reconstruct salinity in coastal settings in which seawater Ba concentration corresponds to salinity as rivers contain much more $\mathrm{Ba}$ than seawater. Incorporation of a number of minor and trace elements is known to vary (greatly) between foraminiferal species, and application of element / Ca ratios thus requires the use of species-specific calibrations. Here we show that calcite $\mathrm{Ba} / \mathrm{Ca}$ correlates positively and linearly with seawater $\mathrm{Ba} / \mathrm{Ca}$ in cultured specimens of two species of benthic foraminifera: Heterostegina depressa and Amphistegina lessonii. The slopes of the regression, however, vary two- to threefold between these two species (0.33 and 0.78, respectively). This difference in $\mathrm{Ba}$ partitioning resembles the difference in partitioning of other elements $(\mathrm{Mg}, \mathrm{Sr}, \mathrm{B}, \mathrm{Li}$ and $\mathrm{Na}$ ) in these foraminiferal taxa. A general trend across element partitioning for different species is described, which may help develop new applications of trace elements in foraminiferal calcite in reconstructing past seawater chemistry.
\end{abstract}

\section{Introduction}

Incorporation of barium $(\mathrm{Ba})$ in foraminiferal calcite is proportional to seawater barium concentrations (e.g., Lea and Boyle, 1989, 1990; Lea and Spero, 1994). Open ocean surface barium concentrations are relatively uniform (Chan et al., 1977; Broecker and Peng, 1982) and since $\left[\mathrm{Ba}^{2+}\right]$ is removed at the surface and regenerated at depth, its vertical concentration resembles that of alkalinity ( $\mathrm{Li}$ and Chan, 1979; Rubin et al., 2003). For this reason, fossil foraminiferal $\mathrm{Ba} / \mathrm{Ca}$ has been used to reconstruct past alkalinity (e.g., Lea, 1995). Locally, seawater $\left[\mathrm{Ba}^{2+}\right]$ can also reflect salinity due to the relatively high $\mathrm{Ba} / \mathrm{Ca}$ of river or meltwater input (Hanor and Chan, 1977; Guay and Falkner, 1997, 1998) and therefore $\mathrm{Ba} / \mathrm{Ca}$ in foraminiferal calcite can be used to reconstruct paleosalinity (Hall and Chan, 2004b; Weldeab et al., 2007, 2014; Bahr et al., 2013). These reconstructions can be complicated by upwelling affecting surface $\mathrm{Ba} / \mathrm{Ca}$ (Lea et al., 1989; Hatch et al., 2013). Moreover, Ba cycling at or close to the seafloor can affect $\mathrm{Ba}$ uptake in benthic foraminifera (Ni Flaithearta et al., 2010). Application of $\mathrm{Ba} / \mathrm{Ca}$ critically depends on the prerequisite that temperature, salinity as such (Lea and Spero, 1994; Hönisch et al., 2011) and photosymbiont activity (Lea and Spero, 1992; Hönisch et al., 2011) do not affect Ba incorporation in foraminiferal shell carbonate. Still, Ba / Ca ratios are known to vary within chamber walls of crust-producing planktonic foraminifera (Eggins et al., 2003; Hathorne et al., 
2009). Like $\mathrm{Mg} / \mathrm{Ca}$, the values for $\mathrm{Ba}$ in crust carbonate are lower, which cannot be (solely) explained by migration to greater water depths during crust formation (Hathorne et al., 2009). This argues for an unknown additional imprint on $\mathrm{Ba}$ incorporation. On an intratest scale, the distributions of $\mathrm{Mg}$ and $\mathrm{Ba}$ within the test wall of Pulleniatina obliquiloculata have been shown to co-vary to some extent, with maximum concentrations often, but not always, coinciding with the organic linings (Kunioka et al., 2006). For some other elements, including $\mathrm{Mg}$ and $\mathrm{Sr}$, incorporation has been shown to be interdependent (e.g., Mewes et al., 2015). Such interdependency, however, varies between pairs of elements and is explained by a combination of simultaneous fractionation by the same process (e.g., Langer et al., 2016) and by involvement of different processes during calcification (Nehrke et al., 2013). These models and experimental results may imply that the incorporation of Ba could also be influenced by these physiological processes and/or the same fractionation process during calcite precipitation (e.g., through lattice distortion; Mucci and Morse, 1983; Mewes et al., 2015).

So far, $\mathrm{Ba} / \mathrm{Ca}$ values have been reported for planktonic (Boyle, 1981; Lea and Boyle, 1991; Lea and Spero, 1992; 1994; Hönisch et al., 2011; Marr et al., 2013; Hoffmann et al., 2014) and low-Mg benthic species (Lea, 1995; Lea and Boyle, 1989, 1990, 1993; Reichart et al., 2003). Although $\mathrm{Mg} / \mathrm{Ca}$ is known to vary greatly between (benthic) foraminiferal species (between $\sim 1$ and $\sim 150 \mathrm{mmol} \mathrm{mol}^{-1}$; Toyofuku et al., 2000; Bentov and Erez, 2006; Wit et al., 2012) $\mathrm{Ba} / \mathrm{Ca}$ ratios, which is only rarely investigated in species producing high-Mg calcite (Evans et al., 2015; Van Dijk et al., 2017). Ba / Ca in planktonic species may be used to reconstruct (changes in) open ocean alkalinity (Lea, 1995), whereas those published for benthics may be more suitable to reconstruct salinity in coastal and shelf seas (Weldeab et al., 2007, 2014; Bahr et al., 2013). The range in $\mathrm{Mg} / \mathrm{Ca}$ is known particularly for benthic foraminifera (e.g., Toyofuku et al., 2011; Sadekov et al., 2014) and interspecies variability in $\mathrm{Ba}$ incorporation may therefore hamper application of (benthic) foraminiferal $\mathrm{Ba} / \mathrm{Ca}$. Here we present results from a culture study using the larger benthic foraminifera, Amphistegina lessonii and Heterostegina depressa, two species with different $\mathrm{Mg} / \mathrm{Ca}\left(\sim 50 \mathrm{mmol} \mathrm{mol}^{-1}\right.$; Segev and Erez, 2006 and $\sim 120 \mathrm{mmol} \mathrm{mol}^{-1}$; Dueñas-Bohórquez et al., 2011, respectively). In these culturing experiments, the range in $\mathrm{Ba} / \mathrm{Ca}$ exceeds the naturally occurring range in seawater to facilitate the testing of underlying controls on barium incorporation. If there is a linear increase in shell $\mathrm{Ba} / \mathrm{Ca}$ $\left(\mathrm{Ba} / \mathrm{Ca}_{\mathrm{cc}}\right)$ with increasing seawater $\mathrm{Ba} / \mathrm{Ca}\left(\mathrm{Ba} / \mathrm{Ca}_{\mathrm{sw}}\right)$, the large range in $\mathrm{Ba} / \mathrm{Ca}$ of the culturing media prepared here will furthermore decrease uncertainty of the obtained $\mathrm{Ba} / \mathrm{Ca}_{\mathrm{cc}}-\mathrm{Ba} / \mathrm{Ca}_{\mathrm{sw}}$ calibration. Our results are compared to $\mathrm{Ba} / \mathrm{Ca}$ in these species from field samples. Together, calibration of $\mathrm{Ba} / \mathrm{Ca}$ in these species against seawater $\mathrm{Ba} / \mathrm{Ca}$ and in the context of other elemental incorporation data, allows the evaluation of and application of incorporated $\mathrm{Ba}$ across a wider range of foraminiferal taxa, with contrasting element composition of their shell.

\section{Methods}

\subsection{Culture media}

To determine Ba / Ca partitioning, benthic foraminiferal culture experiments were set up with five different seawater $\mathrm{Ba} / \mathrm{Ca}$ ratios (54-92 $\mu \mathrm{mol} \mathrm{mol}^{-1}$ ). Media were prepared by increasing $\left[\mathrm{Ba}^{2+}\right]_{\mathrm{sw}}$ while keeping the $\left[\mathrm{Ca}^{2+}\right]_{\mathrm{sw}}$ constant. The range of $\left[\mathrm{Ba}^{2+}\right]$ values used in these experiments exceeds the range of concentrations found naturally and allows the testing of the applicability of partition coefficients under conditions with artificially high seawater $\mathrm{Ba} / \mathrm{Ca}$. Seawater is only slightly undersaturated with respect to barite $\left(\mathrm{BaSO}_{4}\right)$ and an increase in $\left[\mathrm{Ba}^{2+}\right]$ in the sea water will cause barite precipitation (Langer et al., 2009). To be able to increase $\left[\mathrm{Ba}^{2+}\right]$ beyond its natural range, artificial seawater was prepared with lower sulphate contents. All other salts were added according to the recipe of Kester et al. (1967) to produce a total of $5 \mathrm{~L}$ of medium for each treatment. As Amphistegina lessonii and Heterostegina depressa do not grow well in $100 \%$ artificial seawater, the prepared media were mixed with natural seawater in a ratio of 9:1 (Mewes et al., 2014). To double check concentrations and determine potential loss of elements due to precipitation, sorption and/or scavenging, element concentrations of the culture media were determined using inductively coupled plasma optical emission spectrometry (ICP-OES) at the Alfred Wegener Institute in Bremerhaven, except for $\mathrm{Ba}$, which was measured using ICP-MS at Utrecht University (Table 1).

Culture media $\mathrm{pH}$ was adjusted to 8.0 by adding $\mathrm{NaOH}$ (1 M) to the prepared media. Before the start of the experiments, dissolved inorganic carbon (DIC) and total alkalinity were measured at the Alfred Wegener Institute. DIC was measured photometrically in triplicates with a TRAACS CS800 QuAAtro AutoAnalyzer with an average reproducibility of $\pm 10 \mu \mathrm{mol} \mathrm{L}{ }^{-1}$. Alkalinity was calculated from linear Gran plots (Gran, 1952) after triplicate potentiometric titration (Bradshaw et al., 1981) using a TitroLine alpha plus autosampler (Schott Instruments). Parameters of the total carbonate system were calculated from temperature, salinity, DIC and alkalinity using the program CO2SYS adapted to Excel by Pierrot et al. (2006). The equilibrium constants $K 1$ and $K 2$ from Mehrbach et al. (1973), as reformulated by Dickson and Millero (1987), were used (Table 1).

\subsection{Foraminiferal culturing}

Living specimens of A. lessonii and H. depressa were isolated from sediment collected at the tropical aquarium of Burger's Zoo (Arnhem, the Netherlands) in August 2012 and transferred to the Alfred Wegener Institute for the culture experiments. Healthy individuals of A. lessonii showing 
Table 1. Measured concentrations of major and minor ions, temperature, salinity, and carbonate chemistry in the five culture media (A-E).

\begin{tabular}{|c|c|c|c|c|c|}
\hline Treatment & A & B & $\mathrm{C}$ & $\mathrm{D}$ & $\mathrm{E}$ \\
\hline $\mathrm{Ba}\left(\mathrm{nmol} \mathrm{kg}^{-1}\right)$ & 488.5 & 535.5 & 611.0 & 608.4 & 854.6 \\
\hline $\mathrm{Ca}\left(\mathrm{mmol} \mathrm{kg}^{-1}\right)$ & 9.1 & 9.5 & 9.6 & 9.2 & 9.3 \\
\hline $\mathrm{Ba} / \mathrm{Ca}_{\mathrm{sw}}\left(\mathrm{mmol} \mathrm{mol}^{-1}\right)$ & 53.68 & 56.36 & 63.64 & 66.14 & 91.89 \\
\hline $\mathrm{Na}\left(\mathrm{mmol} \mathrm{kg}^{-1}\right)$ & 402 & 416 & 389 & 383 & 384 \\
\hline $\mathrm{B}\left(\mathrm{mmol} \mathrm{kg}^{-1}\right)$ & 11 & 11 & 12 & 11 & 11 \\
\hline $\mathrm{K}(\mathrm{mmol} \mathrm{kg}-1)$ & 0.40 & 0.46 & 0.43 & 0.43 & 0.42 \\
\hline $\mathrm{Mg}\left(\mathrm{mmol} \mathrm{kg}^{-1}\right)$ & 55 & 58 & 59 & 53 & 53 \\
\hline $\operatorname{Sr}\left(\mathrm{mmol} \mathrm{kg}^{-1}\right)$ & 0.11 & 0.11 & 0.12 & 0.11 & 0.11 \\
\hline $\mathrm{Mg} / \mathrm{Ca}_{\mathrm{sw}}\left(\mathrm{mol} \mathrm{mol}^{-1}\right)$ & 6.04 & 6.11 & 6.15 & 5.76 & 5.70 \\
\hline$T\left({ }^{\circ} \mathrm{C}\right)$ & 25 & 25 & 25 & 25 & 25 \\
\hline Salinity & 32.4 & 32.4 & 32.4 & 32.4 & 32.4 \\
\hline $\mathrm{TA}\left(\mu \mathrm{mol} \mathrm{kg}{ }^{-1}\right)$ & 2445 & 2450 & 2662 & 2437 & 2429 \\
\hline $\operatorname{DIC}\left(\mu \mathrm{mol} \mathrm{kg}{ }^{-1}\right)$ & $2244 \pm 3$ & $2246 \pm 6$ & $2464 \pm 7$ & $2236 \pm 7$ & $2228 \pm 9$ \\
\hline$\Omega_{\text {calcite }}$ & 3.9 & 3.9 & 4.0 & 3.9 & 3.9 \\
\hline
\end{tabular}

pseudopodial activity, a dark brown cytoplasm and minimal signs of bleaching were handpicked with a small brush under a Zeiss Stereo microscope and transferred to well plates. Adult specimens of $H$. depressa were picked directly from the aquarium with soft tweezers. After 2 weeks several individuals of both species underwent asexual reproduction. Individual $H$. depressa parent cells produced sufficient numbers of juveniles to study separate clone groups. Approximately 20 juveniles with two or three chambers from the same parent were selected for every treatment and divided over two petri dishes (diameter $55 \mathrm{~mm}$, containing approximately $10 \mathrm{~mL}$ of culture medium). In total, two clone groups were used in the experiments, resulting in a total of at least 40 individuals per treatment. Specimens of A. lessonii did not produce sufficient numbers of juveniles for analysis of separate clone groups. Therefore, approximately 60 juveniles with two or three chambers from different parents were selected per treatment and distributed evenly over three petri dishes. All experiments were carried out in an adjustable incubator (RUMED Rubarth Apparate $\mathrm{GmbH}$ ) at a constant temperature of $25^{\circ} \mathrm{C}$. As both species are symbiont-bearing, a 12:12 light: dark cycle was applied with a constant photon flux density of approximately $250 \mu \mathrm{mol}$ photons $\mathrm{m}^{-2} \mathrm{~s}^{-1}$ during light hours. Pictures were taken weekly under a Zeiss Axiovert 200M inverted microscope and maximal diameters of the shells were measured with the AxioVision software to allow the determination of the chamber addition rates of the foraminifera in the experiments. The experiments were terminated after 6 weeks.

All specimens were fed Dunaliella salina algae every 3 to 4 days. Although A. lessonii hosts symbionts, this foraminiferal species does not exclusively rely on nutrients from their symbionts but also ingests algae (Lee, 2006). To avoid changes in the barium concentration of the culture media, the water in the dishes containing foraminifera was di- luted as little as possible by the solution containing the food for the foraminifera. For this purpose, foraminifera were fed $50 \mu \mathrm{L}$ of a solution containing algae that was centrifuged at $2000 \mathrm{rpm}$ for $10 \mathrm{~min}$. Algae concentrated at the bottom of the tube were transferred to an empty tube with a pipette. To prevent changes in the culture media's carbonate chemistry by algal photosynthesis the algae were killed by heating the concentrated solution in an oven at $90^{\circ} \mathrm{C}$ for $10 \mathrm{~min}$. The cultures were transferred to new petri dishes every week to avoid excessive bacterial growth, potential build-up of waste products and shortage of ions or nutrients. To prevent changes in salinity by evaporation, media were refreshed 3 days after the cultures were transferred to new dishes by pipetting approximately $5 \mathrm{~mL}$ of the old media out of the petri dish and replacing it with the same volume of media from the prepared batch.

\subsection{Sample preparation and analysis}

At the end of the culture experiment, specimens were cleaned by placing them in a $7 \% \mathrm{NaOCl}$ solution for approximately 30 min until completely bleached and organic material was removed from the tests. This cleaning method is shown to have a similar impact on average foraminiferal $\mathrm{Ba} / \mathrm{Ca}$ values as cleaning with $\mathrm{H}_{2} \mathrm{O}_{2}$ and is relatively small (2$3 \mu \mathrm{mol} \mathrm{mol}^{-1}$ ) compared to cleaning with deionized water only (Pak et al., 2004). Specimens were then rinsed three times for approximately $60 \mathrm{~s}$ in deionized water to remove the $\mathrm{NaOCl}$ and any residual salts from the culture solutions. Cleaned foraminifera were put in an oven at $42^{\circ} \mathrm{C}$ until completely dry and mounted on sample holders using doublesided adhesive tape.

Element composition of the calcite was determined using laser ablation inductively coupled plasma mass spectrometry (LA-ICP-MS) at Utrecht University (Reichart et al., 2003). The system consisted of a GeoLas 200Q $193 \mathrm{~nm}$ 
Excimer laser (Lambda Physik) connected to a sector field ICP-MS (Element2, Thermo Scientific). Samples were ablated in a single-volume chamber and the aerosol was carried to the ICP-MS by a helium flow. Monitored masses included ${ }^{23} \mathrm{Na},{ }^{24} \mathrm{Mg},{ }^{26} \mathrm{Mg},{ }^{27} \mathrm{Al},{ }^{43} \mathrm{Ca},{ }^{44} \mathrm{Ca},{ }^{55} \mathrm{Mn},{ }^{88} \mathrm{Sr}$, ${ }^{138} \mathrm{Ba}$, and ${ }^{238} \mathrm{U}$ and calibration was performed using a glass standard (NIST 610) that was ablated three times after every 10-12 foraminiferal samples. Diameter of the ablation crater was set to $80 \mu \mathrm{m}$ for all specimens and the pulse repetition rate was $6 \mathrm{~Hz}$. The ablated calcite was measured and integrated with respect to time. Energy density for the glass was higher than for the foraminifera $\left(5\right.$ and $1 \mathrm{~J} \mathrm{~cm}^{-2}$, respectively). Although the resulting difference in ablation characteristics is not likely to affect obtained foraminiferal element concentrations (Hathorne et al., 2008), foraminiferal element concentrations were compared to those from a calcite standard made in-house with known element concentrations and ablated at the same energy density as the foraminifera (Dueñas-Bohórquez et al., 2009). Relative standard deviation for $\mathrm{Mg} / \mathrm{Ca}$ and $\mathrm{Sr} / \mathrm{Ca}$ based on repeated measurements on this material was $<5 \%$ for both ratios. Due to the lamellar nature of Rotaliid foraminifera, the final chambers are thinnest and are therefore characterized by the largest uncertainty in the estimated average element / Ca ratio. Therefore, the $\mathrm{F}$ chamber was not considered and instead, the F-1 chamber of A. lessonii was ablated for every specimen. For $H$. depressa, walls of the final two chambers were commonly too thin for reliable chemical results and, therefore, the F-2 chamber was analyzed. In addition, for each species, the final 6-7 chambers of 10 sufficiently large specimens (two from each of the five treatments) were ablated to analyze intraspecimen variability in $\mathrm{Ba} / \mathrm{Ca}$, to analyze variability within chamber walls as a function of thickness and to detect potential ontogenetic trends in $\mathrm{Ba}$ incorporation.

Elemental concentrations were calculated from the ablation profiles with the Glitter software, using ${ }^{43} \mathrm{Ca}$ as an internal standard and values from Jochum et al. (2011) for concentrations of elements in the NIST 610. This program integrates the ablation signal after subtracting the background signal to calculate the elemental concentrations. To avoid contaminated intervals of the ablation profile, sections with high ${ }^{27} \mathrm{Al}$ and ${ }^{55} \mathrm{Mn}$ counts were excluded from the analysis since these parts are also often characterized by unusually high $\mathrm{Mg} / \mathrm{Ca}$ not reflecting the actual shell carbonate. Ablation profiles with a duration shorter than $5 \mathrm{~s}$ were rejected as such short profiles are unreliable due to poor counting statistics. Nine out of 188 ablation profiles were rejected for $A$. lessonii and 7 out of 140 profiles from $H$. depressa were discarded, which is less than $5 \%$.

\subsection{Aquarium samples}

To compare the results from cultured specimens with $\mathrm{Ba} / \mathrm{Ca}$ from specimens derived from natural conditions, a number of living specimens of both A. lessonii and H. depressa were isolated from the zoo's stock (i.e., sediment collected at the zoo from which the specimens were isolated; Sect. 2.2) and cleaned and prepared for LA-ICP-MS analyses as described in Sect. 2.3. From both species, seven specimens were ablated twice at the Royal Netherlands Institute for Sea Research (NIOZ) using a NWR193UC (New Wave Research) laser, containing an ArF Excimer laser (Existar) with deep UV $193 \mathrm{~nm}$ wavelength and $<4 \mathrm{~ns}$ pulse duration. Provided that the same reference material is used, the use of multiple laser systems (see above) is shown not to bias obtained foraminiferal element / Ca ratios (De Nooijer et al., 2014a). Laser ablation was performed with an energy density of $1 \mathrm{~J} \mathrm{~cm}^{-2}$ at a repetition rate of $6 \mathrm{~Hz}$ for calcite samples and an energy density of $5 \mathrm{~J} \mathrm{~cm}^{-2}$ for the glass (NIST610) standards. Helium was used as a carrier gas with a flow rate of $0.8 \mathrm{~L} \mathrm{~min}^{-1}$ for cell gas and $0.3 \mathrm{~L} \mathrm{~min}^{-1}$ for cup gas. From the laser chamber to the quadrupole ICPMS (iCAP Q, Thermo Scientific), the He flow was mixed with $\sim 0.4 \mathrm{~L} \mathrm{~min}^{-1}$ nebulizer Ar. Before measuring the samples, the nebulizer gas, extraction lens, collision cell technology (CCT) focus lens and torch position were automatically tuned for the highest sensitivity of ${ }^{25} \mathrm{Mg}$ by laserablating MACS-3. The masses measured by the ICP-MS were ${ }^{23} \mathrm{Na},{ }^{24} \mathrm{Mg},{ }^{25} \mathrm{Mg},{ }^{27} \mathrm{Al},{ }^{43} \mathrm{Ca},{ }^{44} \mathrm{Ca},{ }^{88} \mathrm{Sr}$ and ${ }^{138} \mathrm{Ba}$. JCp-1, MACS-3 and an in-house (foraminiferal) calcite standard (NFHS) were used for quality control and were measured every 10 foraminiferal samples. Internal reproducibility of the analyses was all better than $9 \%$, based on the three different carbonate standards used. Intensity data were integrated, background subtracted, standardized internally to ${ }^{43} \mathrm{Ca}$ and calibrated against the MACS-3 signal using a custom-built MATLAB routine within the program SILLS (Guillong et al., 2008). Since ablation of the NIST SRM 610 and NIST SRM 612 could increase the sodium background, they were only ablated and analyzed at the end of every sequence and cones were cleaned before the next sequence. Accuracy of the analyses was better than $3 \%$, based on comparison of the carbonate standards with internationally reported values (Okai et al., 2002; Wilson et al., 2008). Signals were screened for surface contamination and parts of the outside or inside of the shell with elevated $\mathrm{Mg}, \mathrm{Mn}$ or $\mathrm{Al}$ values were eliminated from the area selected for integration.

Seawater samples from the zoo's aquarium were measured in duplicate using a sector field ICP-MS (Element2, Thermo Scientific). The ICP-MS was run in low-resolution mode (24 cycles) for ${ }^{138} \mathrm{Ba}$ and in medium-resolution mode (24 cycles) for ${ }^{43} \mathrm{Ca}$. Calibration was performed through an external calibration series with increasing concentrations of $\mathrm{Ba}$. 

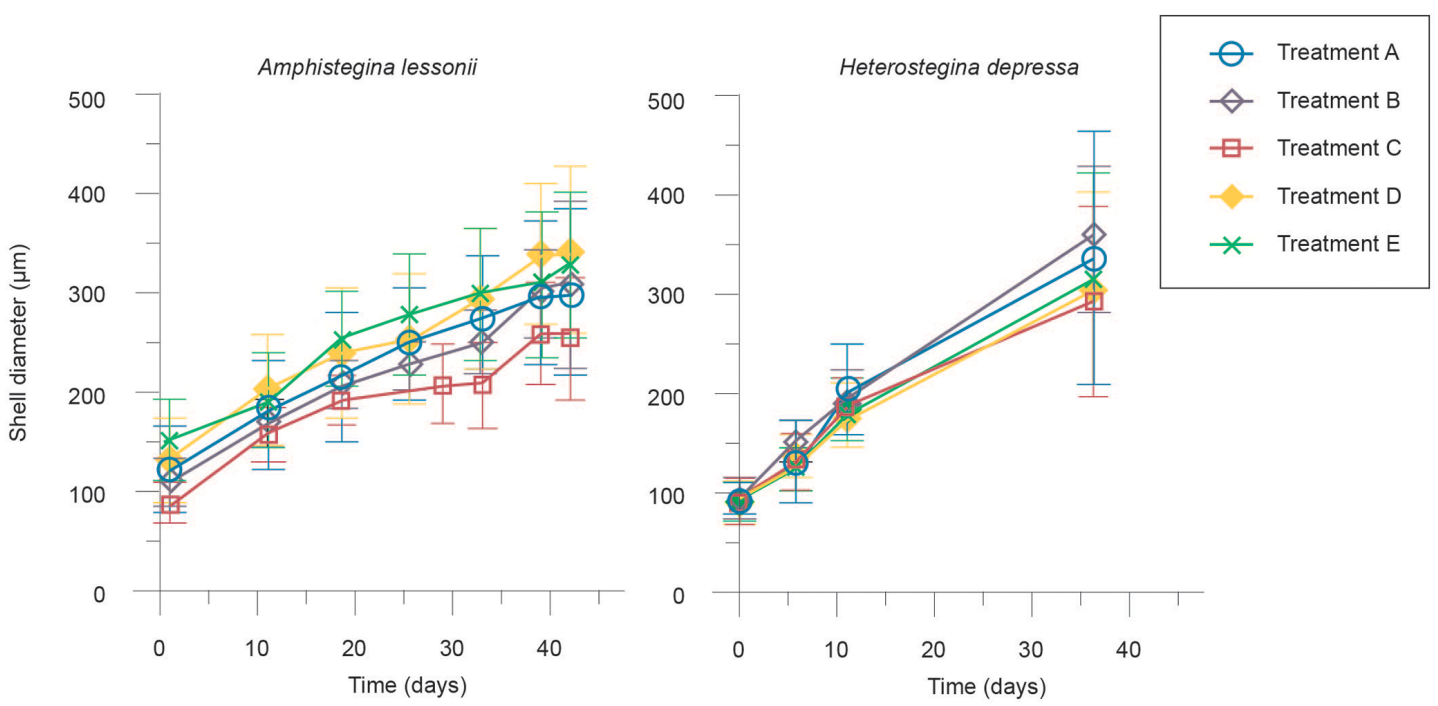

Figure 1. Average increase in shell diameter for A. lessonii (left panel) and $H$. depressa (right panel). Dots represent the average of all analyzed individuals from one treatment. Error bars represent the standard deviation of the mean.

\section{Results}

\subsection{Test diameter increase}

Average shell diameters increased considerably during the experimental period (Fig. 1). Overall, increase in shell diameter did not significantly differ between treatments. Treatment $\mathrm{C}$ (seawater $\mathrm{Ba} / \mathrm{Ca}=64 \mu \mathrm{mol} \mathrm{mol}^{-1}$ ) for $\mathrm{A}$. lessonii, however, shows somewhat reduced chamber addition rates per incubated specimen. This may be the consequence of slightly higher mortality under these conditions and a relatively high number of specimens that did not add any chambers. Although not systematically investigated, two petri dishes from this treatment contained relatively many bleached (i.e., devoid of symbionts) specimens at the end of the 6-week period.

\subsection{Barium incorporation}

Calcite $\mathrm{Ba} / \mathrm{Ca}$ increases linearly with seawater $\mathrm{Ba} / \mathrm{Ca}$ for both species (Fig. 2, Table 2). ANOVA performed on the individual data points combined with regression analyses reveals a significant increase in $\mathrm{Ba} / \mathrm{Ca}_{\mathrm{cc}}$ with $\mathrm{Ba} / \mathrm{Ca}_{\mathrm{sw}}$ for both species (Table 3). Calculated regression slopes result in a $D_{\mathrm{Ba}}$ of $0.326( \pm 0.005)$ for A. lessonii and $0.777( \pm 0.007)$ for $H$. depressa (Fig. 3, solid lines). Regression lines are forced through zero as it seems reasonable to assume that no $\mathrm{Ba}$ is incorporated into calcite when the $\mathrm{Ba}$ concentration in the seawater is zero. Without this forcing, regression slopes would be $\mathrm{Ba} / \mathrm{Ca}_{\mathrm{cc}}=0.34 \times \mathrm{Ba} / \mathrm{C}_{\mathrm{asw}}-1.1$ for $A$. lessonii and $\mathrm{Ba} / \mathrm{Ca}_{\mathrm{cc}}=0.92 \times \mathrm{Ba} / \mathrm{C}_{\mathrm{asw}}-10$ for H. depressa. The resulting partition coefficients $\left(\left(\mathrm{Ba} / \mathrm{Ca}_{\mathrm{cc}}\right) /\left(\mathrm{Ba} / \mathrm{Ca}_{\mathrm{sw}}\right)\right)$ are constant and significantly different between the species (ANOVA) $(\sim 0.3$ for A. lessonii and $\sim 0.8$ for $H$. depressa)
Table 2. Measured $\mathrm{Ba} / \mathrm{Ca}$ and $\mathrm{Mg} / \mathrm{Ca}$ for A. lessonii and $H$. depressa for each treatment.

\begin{tabular}{lrrrrr}
\hline Treatment & A & B & C & D & E \\
\hline A. lessonii & & & & & \\
\hline$n$ & 40 & 43 & 17 & 36 & 43 \\
$\mathrm{Ba} / \mathrm{Ca}\left(\mu \mathrm{mol} \mathrm{mol}^{-1}\right)$ & 15.8 & 19.6 & 18.8 & 22.9 & 29.9 \\
$\mathrm{SD}$ & 3.3 & 3.6 & 3.0 & 4.5 & 5.5 \\
$\mathrm{Mg} / \mathrm{Ca}\left(\mathrm{mmol} \mathrm{mol}^{-1}\right)$ & 37.9 & 49.2 & 70.1 & 89.6 & 80.4 \\
$\mathrm{SD}$ & 10 & 13 & 19 & 33 & 29 \\
\hline H. depressa & & & & & \\
\hline$n$ & 26 & 27 & 23 & 25 & 32 \\
$\mathrm{Ba} / \mathrm{Ca}(\mu \mathrm{mol} \mathrm{mol}$ & \\
$\mathrm{SD}$ & 41.1 & 41.5 & 46.0 & 50.8 & 74.9 \\
$\mathrm{Mg} / \mathrm{Ca}\left(\mathrm{mmol} \mathrm{mol}^{-1}\right)$ & 150 & 135 & 123 & 168 & 177 \\
$\mathrm{SD}$ & 12 & 11 & 6 & 29 & 7 \\
\hline
\end{tabular}

over the range of seawater $\mathrm{Ba} / \mathrm{Ca}$ studied here. The regression line for $\mathrm{Ba} / \mathrm{Ca}_{\mathrm{cc}}$ as a function of $\mathrm{Ba} / \mathrm{Ca}_{\mathrm{sw}}$ for $A$. lessonii corresponds well with that reported for a number of different low-Mg species (Lea and Boyle, 1989).

The aquarium-derived specimens (aquarium samples) had a diameter ranging from 550 to $1180 \mu \mathrm{m}$ (with an average of $975 \mu \mathrm{m}$ ) for A. lessonii and from 1380 to $2340 \mu \mathrm{m}$ (average: $1936 \mu \mathrm{m}$ ) for $H$. depressa. They had an average $\mathrm{Ba} / \mathrm{Ca}$ of $15.4( \pm 2.3 \mathrm{SD}) \mu \mathrm{mol} \mathrm{mol}{ }^{-1}$ for A. lessonii and 35.7 ( $\pm 14 \mathrm{SD}) \mu \mathrm{mol} \mathrm{mol}^{-1}$ for $H$. depressa. In combination with the measured aquarium's seawater $\mathrm{Ba} / \mathrm{Ca}$ of 35.7 ( $\pm 3.9 \mathrm{SD}) \mu \mathrm{mol} \mathrm{mol}{ }^{-1}$, the partition coefficients for Ba vary between 0.43 and 1.0 for $A$. lessonii and $H$. depressa, respectively. The aquarium-derived data are consistent with the 


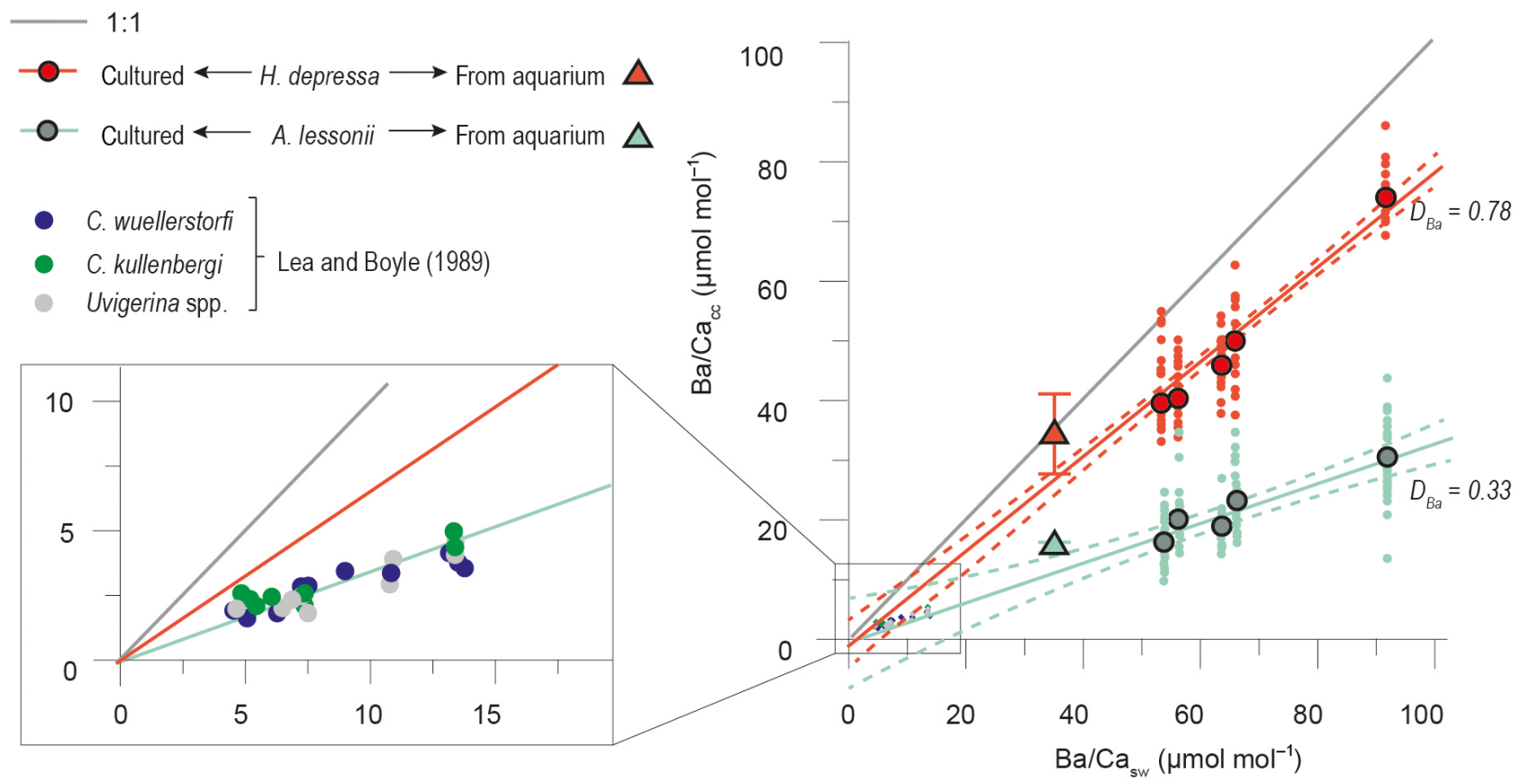

Figure 2. Foraminiferal $\mathrm{Ba} / \mathrm{Ca}$ as a function of seawater $\mathrm{Ba} / \mathrm{Ca}$. Light circles indicate individual laser ablation measurements. Larger, darker shaded circles represent the average $\mathrm{Ba} / \mathrm{Ca}_{\mathrm{cc}}$ for one treatment. Relative standard deviation varies between 16 and $20 \%$ for $\mathrm{Ba} / \mathrm{Ca}$ in A. lessonii and between 5 and $15 \%$ for $H$. depressa. Average $\mathrm{Ba} / \mathrm{Ca}$ ratios for the two species collected from the aquarium are indicated by triangles $( \pm 1 \mathrm{SD})$ and were not taken into account when calculating the regression. Calculated regressions are accompanied by their $95 \%$ confidence intervals (dashed lines) over the $\mathrm{Ba} / \mathrm{Ca}_{\mathrm{sw}}$ range from 50 to $90 \mu \mathrm{mol} \mathrm{mol}{ }^{-1}$. Data from Lea and Boyle (1989) are plotted additionally for comparison.
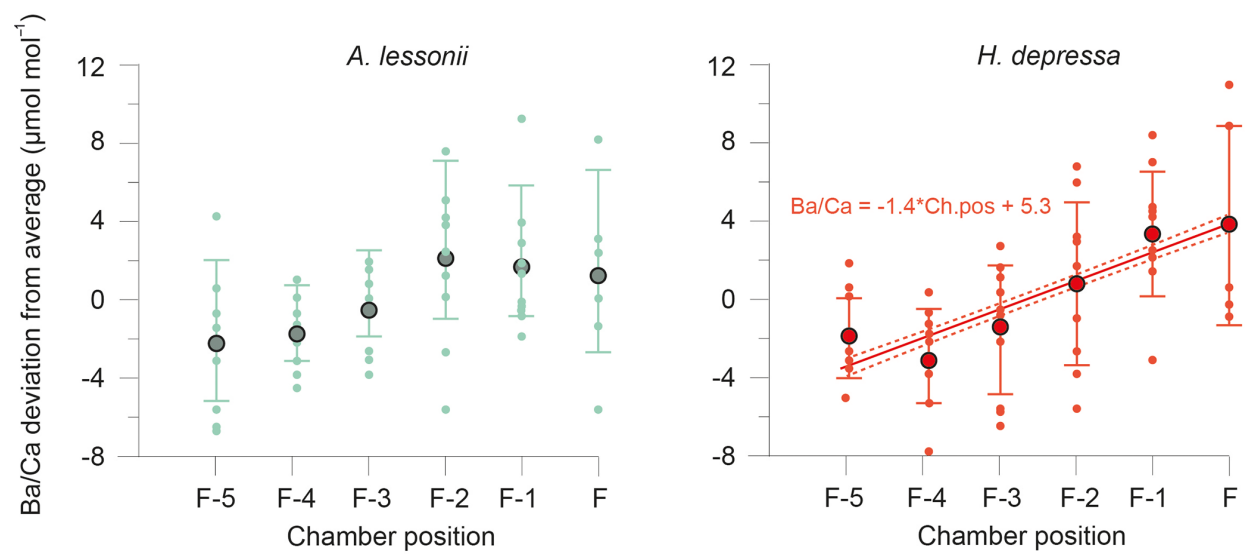

Figure 3. Average (large, darker shaded circles) and single-chamber measurement (lighter circles) $\mathrm{Ba} / \mathrm{Ca}_{\mathrm{cc}}$ ratios, expressed as their deviation from the mean shell $\mathrm{Ba} / \mathrm{Ca}_{\mathrm{cc}}$ for A. lessonii (left) and H. depressa. Error bars represent the standard deviation of the mean; the dashed lines in the right panel indicate the $95 \%$ confidence intervals for the linear regression.

controlled-growth-derived data, but they were not used in the regression analysis (Fig. 2) since the conditions (e.g., carbonate chemistry) under which the specimens from the aquarium were grown were not determined as precisely and accurately as in our culturing experiment. Including these data in the linear regression (Fig. 2) would change the sensitivity from 0.78 to 0.77 for $H$. depressa and from 0.33 to 0.32 for $A$. lessonii.

\subsection{Intrachamber variability in $\mathrm{Ba} / \mathrm{Ca}$}

From both species, 10 specimens were used to quantify the relation between ontogeny (i.e., size-dependent) and $\mathrm{Ba}$ incorporation into foraminiferal calcite. For this purpose, the final 6-7 chambers of these individuals were ablated (Fig. 3). With the selected spot diameter $(80 \mu \mathrm{m})$, ablation of a small amount of material of adjacent chambers could not always be 
Table 3. Parameters of the regression analysis and ANOVA tests for significance of the regression. Both average $\mathrm{Ba} / \mathrm{Ca} \mathrm{cc}_{\mathrm{cc}}$ of each experimental condition $(n=5)$ and all chamber-specific $\mathrm{Ba} / \mathrm{Ca}_{\mathrm{cc}}(n=133 / 179)$ ratios were tested versus the $\mathrm{Ba} / \mathrm{Ca}$ of the five treatments.

\begin{tabular}{llrr|rr}
\hline & & & $\begin{array}{r}\text { Regression } \\
\text { analysis }\end{array}$ & \multicolumn{2}{c}{ ANOVA } \\
\hline Parameter & Species & $n$ & $R^{2}$ & $F$ value & $p$ value \\
\hline $\mathrm{Ba} / \mathrm{Ca}_{\mathrm{sw}}$ vs. $\mathrm{Ba} / \mathrm{Ca}_{\mathrm{cc}}$ & H. depressa & 133 & 0.88 & 940 & $<0.01$ \\
$\mathrm{Ba} / \mathrm{Ca}_{\mathrm{sw}}$ vs. average $\mathrm{Ba} / \mathrm{Ca}_{\mathrm{cc}}$ & A. lessonii & 179 & 0.56 & 227 & $<0.01$ \\
& H. depressa & 5 & 0.99 & 247 & $<0.01$ \\
& A. lessonii & 5 & 0.91 & 32 & 0.011 \\
\hline
\end{tabular}

avoided. Some chamber walls, particularly of the youngest (i.e., built latest) chambers, were too thin for reliable measurements and were excluded from further consideration.

Since these specimens were cultured at different $\mathrm{Ba} / \mathrm{Ca}_{\mathrm{sw}}$ ratios, the interchamber variability is expressed as the difference of a single-chamber $\mathrm{Ba} / \mathrm{Ca}$ and the individual's average $\mathrm{Ba} / \mathrm{Ca}$. Positive single-chamber values indicate higherthan-average values, whereas negative values indicate singlechamber $\mathrm{Ba} / \mathrm{Ca}$ below that individual's average $\mathrm{Ba} / \mathrm{Ca}$ (Fig. 3).

In H. depressa, $\mathrm{Ba} / \mathrm{Ca}_{\mathrm{cc}}$ increases significantly with subsequently new chambers added (Fig. 3). Regression analysis reveals an average increase of $1.43 \mu \mathrm{mol} \mathrm{mol}^{-1} \mathrm{Ba} / \mathrm{Ca}_{\mathrm{cc}}$ with every chamber added (Table 4 ). $\mathrm{Ba} / \mathrm{Ca}_{\mathrm{cc}}$ appears to decrease with chamber position in A. lessonii, although the ANOVA $p$ value shows that this is statistically not significant. Still, removing one single outlier already results in a $p$ value lower than 0.01 , indicating that the current data set does not allow the rejection of the presence of a trend for $A$. lessonii.

\subsection{Relation between incorporation of barium and magnesium}

Combining data from all five treatments, average $\mathrm{Mg} / \mathrm{Ca}$ of A. lessonii was $64 \mathrm{mmol} \mathrm{mol}^{-1}$, with a relative standard deviation of $47 \%$. Within treatments, the variability in $\mathrm{Mg} / \mathrm{Ca}$ is considerably lower (between 27 and $37 \%$ ). Average $\mathrm{Mg} / \mathrm{Ca}$ in $H$. depressa was $152 \mathrm{mmol} \mathrm{mol}^{-1}$, with a standard deviation of $25 \mathrm{mmol} \mathrm{mol}^{-1}(16 \%)$. Within treatments, the relative standard deviation ranged from $4.1 \%$ (treatment $\mathrm{E}$ ) to $17 \%$ (treatment $\mathrm{D}$ ). The speciesspecific single-chamber $\mathrm{Mg} / \mathrm{Ca}$ and $\mathrm{Ba} / \mathrm{Ca}$ ratios combined for all treatments are positively and significantly related (Fig. 4). For A. lessonii, $\mathrm{Mg} / \mathrm{Ca}=3.1 \times \mathrm{Ba} / \mathrm{Ca}-3.6$ ( $t$ value $=12.2, \quad p<0.01$ for the slope of the regression) and for $H$. depressa, $\mathrm{Mg} / \mathrm{Ca}=1.1 \times \mathrm{Ba} / \mathrm{Ca}+92$ ( $t$ value $=14.8, \quad p<0.01$ for the slope). The slopes of these two regressions (3.1 and 1.1) are significantly different: this is calculated by $z=\left(a_{\text {Heterostegina }}-\right.$ $\left.a_{\text {Amphistegina }}\right) / \sqrt{ }\left(\mathrm{SE}_{a, \text { Heterostegina }}^{2}+\mathrm{SE}_{a, \text { Heterostegina }}^{2}\right)$, in which $a$ is the value for the regression's slope and $\mathrm{SE}_{a}$ is the slope's
Table 4. ANOVA parameters of single-chamber measurements.

\begin{tabular}{llrr}
\hline ANOVA & Species & $F$ & $p$ \\
\hline A. lessonii & 2.47 & 0.06 \\
A. lessonii (F-1 and F-2) & 0.11 & 0.744 \\
H. depressa & 6.09 & $<0.01$ \\
\hline
\end{tabular}

associated standard error. For the slopes of the $\mathrm{Mg} / \mathrm{Ca}-$ $\mathrm{Ba} / \mathrm{Ca}$ regressions for Amphistegina and Heterostegina, the resulting $z$ score is higher than $>7$, indicating that the two slopes are significantly different.

When comparing the single-chamber $D_{\mathrm{Ba}}$ with $D_{\mathrm{Mg}}$ of all data combined, the partition coefficient for $\mathrm{Mg}$ is over 30 times lower than that of $\mathrm{Ba}$ (Fig. 4). Over the range in $\mathrm{Ba} / \mathrm{Ca}_{\mathrm{sw}}$ studied here, the relation between $D_{\mathrm{Ba}}$ and $D_{\mathrm{Mg}}$ is linear within both species. For A. lessonii, $D_{\mathrm{Mg}}=40 \times D_{\mathrm{Ba}}-$ $2.0(t$ value $=7.3, p<0.01$ for the slope of the regression $)$ and for $H$. depressa, $D_{\mathrm{Mg}}=29 \times D_{\mathrm{Ba}}+3.8(t$ value $=6.5$, $p<0.01$ for the slope). The slopes of these two regressions (40 and 29) are not significantly different ( $z$ score 1.6$)$. When combining the data from both species, the regression equals $D_{\mathrm{Mg}}=34 \times D_{\mathrm{Ba}}+0.073(t$ value $=29.9, p<0.01$ for the slope).

\section{Discussion}

\subsection{Test diameter increase}

The range of $\mathrm{Ba}$ concentrations used in the experiments did not influence the increase in shell diameter of either foraminiferal species (Fig. 1). Compared to H. depressa, increases in shell diameter (which is proportional to the chamber addition rate) for $A$. lessonii were slightly more variable. To prevent barite precipitation it was necessary to reduce the sulphate concentration below that typically measured in natural seawater. Sulphate concentrations between 0.1 and $1 \mathrm{mmol} \mathrm{L}^{-1}$ do not affect inorganic calcite growth (Reddy and Nancollas, 1976), but a decrease in growth rates of approximately $30 \%$ was observed in coccolithophores growing in artificial seawater with a sulphate concentration $10 \%$ that 

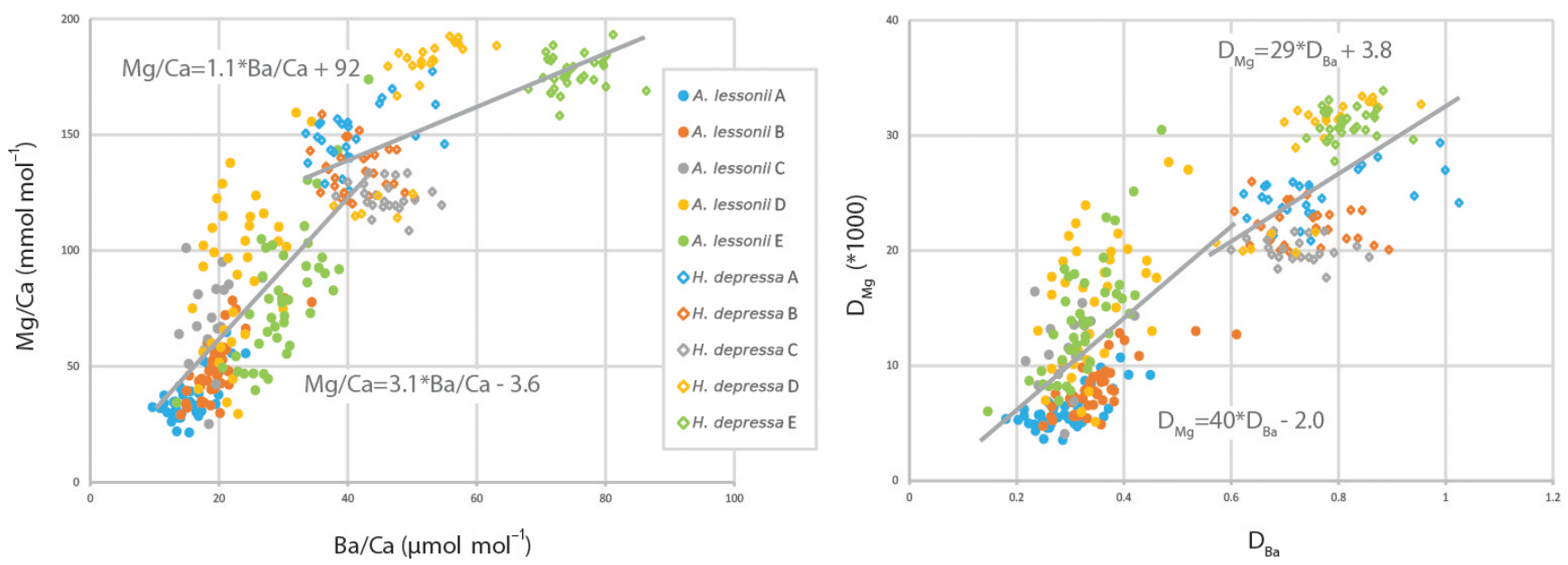

Figure 4. Relation between the $\mathrm{Ba} / \mathrm{Ca}$ and $\mathrm{Mg} / \mathrm{Ca}$ (left panel) and the partition coefficients for $\mathrm{Ba}$ and $\mathrm{Mg}$ (right panel). Every dot represents one single-chamber measurement. The data for $A$. lessonii are indicated by circles; those for $H$. depressa are represented by open diamonds. Every treatment (A-E, Table 1) is indicated by a separate color.

of natural seawater (Langer et al., 2009). Although coccolithophores and foraminifera may respond differently to lowered sulphate concentrations, this reduction could have hampered growth of the specimens in our culturing experiment. Chamber addition rates of $A$. lessonii in a culture setup with sulphate concentrations similar to those of natural seawater (Mewes et al., 2014) were approximately $20 \%$ higher than chamber addition rates observed in our experiments. Since these experiments were not performed simultaneously using specimens from the same batch, it is not straightforward to compare absolute rates and therefore the $20 \%$ difference cannot unambiguously be attributed to sulphate concentration (Hoppe et al., 2011). Unfortunately no data exist on the effect of reduced sulphate concentrations on the uptake of trace elements in foraminiferal calcite. However, Langer et al. (2009) demonstrated that sulphate limitation had no discernible effect on $\mathrm{Ba}$ incorporation in coccolithophore calcite.

\subsection{Barium incorporation}

The variability in $\mathrm{Ba} / \mathrm{Ca}$ between individual ablation craters is considerable, but the average foraminiferal $\mathrm{Ba} / \mathrm{Ca}$ shows a consistent relation with seawater $\mathrm{Ba} / \mathrm{Ca}$. This implies that the observed variability is a reflection of the inhomogeneous distribution in the test and is hence filtered out when averaging. This is similar to the behavior for $\mathrm{Mg}$ and $\mathrm{Sr}$ (Sadekov et al., 2008; Wit et al., 2012; De Nooijer et al., 2014a) and underscores the power of single-chamber analyses. If present, inhomogeneity in test wall $\mathrm{Ba} / \mathrm{Ca}$ in combination with different cross sections sampled during the ablation potentially account for the observed variability. This would imply that although large differences are observed within a test wall, the average still reliably reflects seawater concentration (this paper) and for $\mathrm{Mg}$, still reflects seawater temper- ature (Hathorne et al., 2009). Comparing within-specimen and between-specimen variability, De Nooijer et al. (2014a) showed that within-specimen variability does not account for all of the observed variability in $\mathrm{Mg} / \mathrm{Ca}$ in Ammonia tep$i d a$. This seems to be similar for $\mathrm{Ba} / \mathrm{Ca}$ (compare Fig. 4 in this paper with Fig. 5 from De Nooijer et al., 2014a), which would mean that at least 20 chambers need to be analyzed to reach a $5 \%$ relative precision (De Nooijer et al., 2014a). This is not limited by the analytical precision, but rather is due to inherent biological interchamber and interspecimen variability. To reduce ontogenetic variability (in, for example, paleoceanographic applications where complete specimens are measured), a narrow size fraction should be analyzed.

Incorporation of $\mathrm{Ba}$ in $H$. depressa shows a partitioning that is about 2.5 times higher than in A. lessonii. Such a large offset of $D_{\mathrm{Ba}}$ between benthic species fits previously reported (differences in) partition coefficients for $\mathrm{Ba}$. Lea and Boyle (1989) found $D_{\mathrm{Ba}}=0.37 \pm 0.06$ for Cibicidoides wuellerstorfi, Cibicidoides kullenbergi and Uvigerina spp. for a series of core tops, comparable to the partition coefficient reported here for A. lessonii $(0.33 \pm 0.022$, Fig. 2). In contrast, partition coefficients for $\mathrm{Ba}$ in planktonic foraminifera are roughly only twice as low as these benthic foraminiferal partitioning coefficients (0.14-0.19; Hönisch et al., 2011; Lea and Boyle, 1991; Lea and Spero, 1992). Although temperature, $\mathrm{pH}$, salinity and pressure were initially proposed as potential explanations for the offset between planktonic and benthic $D_{\mathrm{Ba}}$ (Lea and Boyle, 1991; Lea and Spero, 1992), studies by Lea and Spero (1994) and Hönisch et al. (2011) showed no significant impact of temperature, $\mathrm{pH}$ and salinity on $\mathrm{Ba}$ incorporation into planktonic foraminiferal calcite. This would leave hydrostatic pressure to explain the difference between benthic and planktonic species. Conversely, van Dijk et al. (2017) showed that in a 


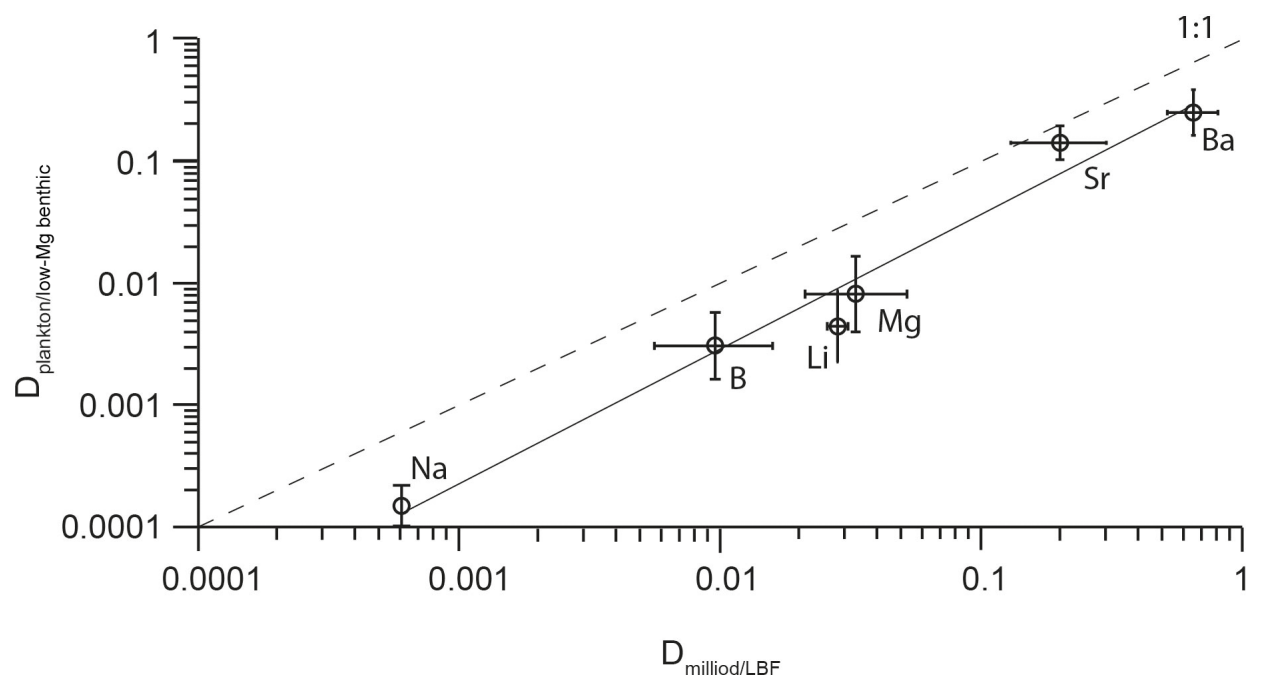

Figure 5. Partition coefficients for $\mathrm{Li}, \mathrm{B}, \mathrm{Na}, \mathrm{Mg}, \mathrm{Sr}$ and $\mathrm{Ba}$ for two groups of foraminifera (large benthic foraminifera $+\mathrm{Miliolids}$ and the low-Mg species). Data on which the average partition coefficients are based are listed in the Supplement. The ranges indicate the maximum range in published partition coefficients. The linear regression between the partition coefficients for these two groups is described by: $D_{\text {plankton/low-Mg benthic }}=0.3992 \times D_{\text {miliolid/LBF }}+0.0081$. Elemental results for Miliolid species are confined to $\mathrm{Mg} / \mathrm{Ca}$ and $\mathrm{Sr} / \mathrm{Ca}$. $\mathrm{Li}$ / Ca ratios were taken from Delaney et al. (1985), Hall and Chan (2004a), Marriott et al. (2004), Yu et al. (2005), Ni et al. (2007), Bryan and Marchitto (2008), Hathorne et al. (2009), Dawber and Tripati (2012), and Evans et al. (2015); B / Ca ratios are from Yu et al. (2005), Yu and Elderfield (2007), Foster (2008), Hendry et al. (2009), Allen et al. (2011, 2012), Dawber and Tripati (2012), Babila et al. (2014), and Kaczmarek et al. (2015); Na / Ca ratios are from Delaney et al. (1985), Ni et al. (2007), Bian and Martin (2010), Wit et al. (2013) and Evans et al. (2015); Mg / Ca ratios are from Toyofuku et al. (2000), Raja et al. (2005), Yu et al. (2005), Elderfield et al. (2006), Segev and Erez (2006), Hendry et al. (2009), Dueñas-Bohórquez et al. (2009, 2011), Dawber and Tripati (2012), Wit et al. (2012, 2013), Babila et al. (2014), De Nooijer et al. (2014a), Sadekov et al. (2014), and Evans et al. (2015). Foraminiferal Sr / Ca ratios are taken from Raja et al. (2005), Yu et al. (2005), Hendry et al. (2009), Dueñas-Bohórquez et al. (2009, 2011), Dawber and Tripati (2012), Wit et al. (2013), De Nooijer et al. (2014a), and Evans et al. (2015). Ba / Ca ratios are from this study, Lea and Boyle (1989, 1991), Lea and Spero (1994), Hall and Chan (2004b), Ni et al. (2007), Hönisch et al. (2011), and Evans et al. (2015).

number of larger benthic foraminifera, $\mathrm{Ba} / \mathrm{Ca}$ is positively influenced by $p \mathrm{CO}_{2}$. Our observations show, however, that the observed differences in $D_{\mathrm{Ba}}$ between $H$. depressa and $A$. lessonii and also the offset with the planktonic species are inherent to these species. A small impact of environmental parameters other than seawater $\mathrm{Ba} / \mathrm{Ca}$ may account for the slightly higher $D_{\mathrm{Ba}}$ in the foraminifera taken from the aquarium compared to the cultured ones (Fig. 2). The overall differences in partitioning seem to coincide with different taxonomic groups, which may indicate that foraminifera may differ in their controls on transporting ions from seawater to the site of calcification. For example, the contribution of transmembrane transport versus that of seawater transport (i.e., leakage, Nehrke et al., 2013, or vacuolization, Erez, 2003) may vary between species and thereby account for differences in $\mathrm{Mg} / \mathrm{Ca}, \mathrm{Ba} / \mathrm{Ca}$, and so forth (Nehrke et al., 2013).

\subsection{Interchamber variability of $\mathrm{Ba} / \mathrm{Ca}_{\mathrm{cc}}$}

In both species cultured here, $\mathrm{Ba} / \mathrm{Ca}_{\mathrm{cc}}$ decreases significantly from the largest (i.e., built latest in life) towards the smaller chambers (Fig. 3). Observed trends were not significantly different between $A$. lessonii and $H$. depressa, sug- gesting that $\mathrm{Ba} / \mathrm{Ca}_{\mathrm{cc}}$ decreases at the same rate with size, despite the overall difference in $\mathrm{Ba} / \mathrm{Ca}_{\mathrm{cc}}$ (Fig. 3). Since we always analyzed chambers at the same position (F-1 for $A$. lessonii and F-2 for $H$. depressa) and since the final size of the cultured specimens was similar between treatments (Fig. 1), ontogenetic trends in $\mathrm{Ba} / \mathrm{Ca}$ do not influence the trends in $\mathrm{Ba} / \mathrm{Ca}$ between treatments (Fig. 2). Several other studies showed that element / Ca ratios can vary with chamber position. Raitzsch et al. (2011), for example, reported increasing $\mathrm{B} / \mathrm{Ca}$ and decreasing $\mathrm{Mg} / \mathrm{Ca}$ towards younger chambers in the benthic Planulina wuellerstorfi. Such patterns may be related to changes in the surface-to-volume ratio or relative changes in vital effects as foraminifera grow larger. For example, $\mathrm{pH}$ reduction in the foraminiferal microenvironment is related to the specimen's size (Glas et al., 2012) and may thereby affect the chemical speciation of minor and trace element, which in turn, may determine their uptake rates. Hönisch et al. (2011), however, showed that seawater $\mathrm{pH}$ has no noticeable effect on Ba incorporation in planktonic foraminiferal calcite, rendering changes in the $\mathrm{pH}$ of the foraminiferal microenvironment an unlikely explanation to account for the observed chamber-to-chamber variability in $\mathrm{Ba} / \mathrm{Ca}$. Alternatively, changes in the metabolic 
rate, the instantaneous calcification rate or a different partitioning between the impacts of the life processes may lead to the observed ontogenetic trend.

Bentov and Erez (2006) argued that decreasing $\mathrm{Mg} / \mathrm{Ca}$ with foraminifera test size could be explained by relatively high $\mathrm{Mg}$ concentrations at or near the primary organic sheet (POS), which is the organic matrix on which the first layer of calcite precipitates during the formation of a new chamber. With the formation of a new chamber, a low-Mg calcite layer is deposited over all existing chambers, so that the high-Mg phase is diluted as more layers are deposited (Bentov and Erez, 2006). Future studies may indicate whether $\mathrm{Ba} / \mathrm{Ca}$ is also heterogeneously distributed within chamber walls, by, for example, being enriched close to the POS (Kunioka et al., 2006). If this is the case, lamellar calcification mode may also result in changing $\mathrm{Ba} / \mathrm{Ca}$ with chamber position.

\subsection{Coupled incorporation of barium and magnesium}

If incorporation of $\mathrm{Ba}$ and $\mathrm{Mg}$ (and $\mathrm{Na}, \mathrm{Sr}$ and $\mathrm{B}$ ) are physically linked during biomineralization, interspecies differences in composition may likely be correlated across the various elements. The correlation between $\mathrm{Mg} / \mathrm{Ca}$ and $\mathrm{Ba} / \mathrm{Ca}$ within and between species (Fig. 4) suggests that these two elements are simultaneously affected during their incorporation. The relationship between $\mathrm{Mg} / \mathrm{Ca}$ and $\mathrm{Ba} / \mathrm{Ca}$ is different between the two species, which may be (partly) caused by the variability in seawater chemistry between treatments (i.e., seawater $\mathrm{Ba} / \mathrm{Ca}$ and $\mathrm{Mg} / \mathrm{Ca}$; Table 1). Alternatively, incorporation of $\mathrm{Mg}$ in $\mathrm{H}$. depressa may be close to the maximum concentration of $\mathrm{Mg}$ that can be incorporated into a calcite crystal lattice at ambient conditions (Morse et al., 2007). This may result in an overall asymptotic relationship between $\mathrm{Mg} / \mathrm{Ca}$ and $\mathrm{Ba} / \mathrm{Ca}$ as $\mathrm{Mg} / \mathrm{Ca}$ approaches $\sim 200 \mathrm{mmol} \mathrm{mol}^{-1}$ (Fig. 4).

When correcting for the different seawater $\mathrm{Ba} / \mathrm{Ca}$ and $\mathrm{Mg} / \mathrm{Ca}$ between treatments, incorporated $\mathrm{Ba}$ and $\mathrm{Mg}$ correlate similarly within as well as between the two species studied here (Fig. 4). This suggests that these elements are coupled during biomineralization itself and that the ratio of $\mathrm{Ba}$ and $\mathrm{Mg}$ in seawater is preserved during calcification by these species of foraminifera. When comparing the relation between $\mathrm{Ba} / \mathrm{Ca}$ and $\mathrm{Mg} / \mathrm{Ca}$ from other benthic species (e.g., Lea and Boyle, 1989, Fig. 2; Lea and Spero, 1994; Hönisch et al., 2011; Evans et al., 2015), the coupling between Ba and $\mathrm{Mg}$ incorporation is likely similar across a wide range of benthic foraminiferal species.

\subsection{Biomineralization and element incorporation}

Foraminiferal biomineralization determines the incorporation of many elements and fractionation of many isotopes during the production of new chambers, as indicated by overall large compositional differences between inorganically precipitated and foraminiferal calcite (Erez, 2003; Ben- tov and Erez, 2006; Nehrke et al., 2013; De Nooijer et al., 2014b). For example, $\mathrm{Mg} / \mathrm{Ca}$ ratios in many species are orders of magnitude lower than what is expected from inorganic precipitation experiments. Additionally, $\mathrm{Mg} / \mathrm{Ca}$ varies considerably between foraminiferal species and especially between species known to have different calcification strategies (Bentov and Erez, 2006; Toyofuku et al., 2011; Wit et al., 2012; De Nooijer et al., 2009, 2014b). Other elements such as $\mathrm{Sr}$ (e.g., Elderfield et al., 2000) and B / Ca (e.g., Allen et al., 2012) also vary significantly between species. Generally, concentrations for these elements correlate within taxa and hence species incorporating relatively much $\mathrm{Mg}$ also have high (for example) $\mathrm{Sr} / \mathrm{Ca}, \mathrm{B} / \mathrm{Ca}$ and $\mathrm{Na} / \mathrm{Ca}$. Miliolids and many large benthic foraminifera $(\mathrm{LBF})$ produce calcite with $\mathrm{Mg} / \mathrm{Ca}$ of up to $100-150 \mathrm{mmol} \mathrm{mol}^{-1}$ (Toyofuku et al., 2000; Dueñas-Bohórquez et al., 2011; Sadekov et al., 2014; Evans et al., 2015), while most planktonic and symbiont-barren benthic foraminifera produce test calcite with $\mathrm{Mg} / \mathrm{Ca}$ values ranging from 1 to $10 \mathrm{mmol} \mathrm{mol}^{-1}$ (e.g., Nürnberg et al., 1996; Elderfield et al., 2002; Lear et al., 2010; Wit et al., 2012; De Nooijer et al., 2014b). The same distinction is observed for B / Ca (compare, for example, Allen et al., 2012, and Kazcmarek et al., 2015), Li / Ca (Lear et al., 2010, versus Evans et al., 2015), $\mathrm{Na} / \mathrm{Ca}$ (Wit et al., 2013, versus Evans et al., 2015) and Sr / Ca (e.g., DueñasBohórquez et al., 2011). The correlation between relatively high (for example) $\mathrm{Mg} / \mathrm{Ca}, \mathrm{Sr} / \mathrm{Ca}$ and $\mathrm{B} / \mathrm{Ca}$ corresponds to the observed trends in the data presented here for $\mathrm{Ba} / \mathrm{Ca}$ and $\mathrm{Mg} / \mathrm{Ca}$ in $H$. depressa and A. lessonii (Fig. 4). The $\mathrm{Mg} / \mathrm{Ca}$ in the former species is approximately 2.5 times that of the latter, which is similar to the difference observed in $\mathrm{Ba} / \mathrm{Ca}$ ratios between these species and implies that $\mathrm{Ba}$ changes in concert with $\mathrm{Mg}$, which is consistent with the single-chamber correlation between $\mathrm{Mg} / \mathrm{Ca}$ and $\mathrm{Ba} / \mathrm{Ca}$ (Fig. 4). Such a change could potentially be caused inorganically by differences in $\mathrm{Mg}$ opening up the crystal lattice in such a way that it can accommodate more or less Ba. Such a mechanism is described for $\mathrm{Mg}$ and $\mathrm{Sr}$ (e.g., Morse and Bender, 1990; Mucci and Morse, 1983; Mewes et al., 2015; Langer et al., 2016) and may also apply to Ba incorporation and the influence of $\mathrm{Mg}$ ions that increase stress in the calcite crystal lattice. Unless the strain of incorporated $\mathrm{Mg}$ ions does not increase linearly with its concentration, the covariance between $\mathrm{Mg}$ and in this case Ba may well be interrelated during an earlier stage of the biomineralization process, e.g., during their transport from the surrounding seawater into the site of calcification (Erez, 2003; De Nooijer et al., 2014b).

Interestingly, the partitioning of different elements is not the same between taxa. For example, $\mathrm{Sr} / \mathrm{Ca}$ in $\mathrm{LBF}$ is approximately twice as high (Dueñas-Bohorquez et al., 2011; Evans et al., 2015) as in planktonic species (Elderfield et al., 2002; Dueñas-Bohórquez et al., 2009; Hendry et al., 2009), whereas the ratio between the $D_{\mathrm{Mg}}$ of these groups is between 10 and 100 (see above). Comparing the offset of $D$ between groups as a function of $D$ itself shows an approx- 
imate logarithmic correlation (Fig. 5). The distinction between the two groups on the basis of their element signature coincides with known differences in biomineralization controls. Element controls in low-Mg species are thought to be determined by (highly) selective trans-membrane ion transporters, (limited) leakage of seawater into the site of calcification and/or selective $\mathrm{Mg}^{2+}$ removal (Nehrke et al., 2013; De Nooijer et al., 2014b; Toyofuku et al., 2017). Miliolid foraminifera belong to the high-Mg foraminiferal group and are known to secrete their calcite within vesicles that are hypothesized to contain seawater, which may be modified after endocytosis (Hemleben et al., 1986; Ter Kuile and Erez, 1991; De Nooijer et al., 2009). These intracellular vesicles may therefore contain relatively high concentrations of $\mathrm{Mg}^{2+}, \mathrm{Ba}^{2+}$ and other ions present in seawater, although so far mainly $\mathrm{Sr} / \mathrm{Ca}$ and $\mathrm{Mg} / \mathrm{Ca}$ of Miliolid foraminifera have been published (Supplement). The biomineralization of nonMiliolid, intermediate- and high-Mg benthic foraminifera may employ characteristics of both these types of calcification and therefore incorporate moderate to high concentrations of elements (see Segev and Erez, 2006).

\section{Conclusions}

Results from this study indicate that differences in $D_{\mathrm{Ba}}$ between species of foraminifera can be relatively large. This implies that species-specific Ba partition coefficients need to be applied to reconstruct past $\mathrm{Ba} / \mathrm{Ca}_{\mathrm{sw}}$ and/or salinity (Lea and Boyle, 1989; Weldeab et al., 2007; Hoffmann et al., 2014; Evans et al., 2015). Moreover, our results underscore the necessity to account for size-related effects on $\mathrm{Ba} / \mathrm{Ca}_{\mathrm{cc}}$. This effect may bias obtained $\mathrm{Ba} / \mathrm{Ca}_{\mathrm{cc}}$ particularly when using single-chamber measurements. When determining $\mathrm{Ba} / \mathrm{Ca}_{\mathrm{cc}}$ by dissolution of whole shells, the contribution of smaller chambers (with lower $\mathrm{Ba} / \mathrm{Ca}_{\mathrm{cc}}$ ) is relatively small compared to a specimen's overall $\mathrm{Ba} / \mathrm{Ca}$ and thus does not affect average values. Our results also show that within species as well as between species, single-chambered $\mathrm{Mg} / \mathrm{Ca}$ and $\mathrm{Ba} / \mathrm{Ca}$ are linearly correlated. The difference in $\mathrm{Ba} / \mathrm{Ca}$ between the two species studied here fits with previously observed variability in element / $\mathrm{Ca}$ ratios between foraminifera taxa and likely reflects differences in their biomineralization mechanisms.

Data availability. The data on which this publication is based, can be found through the following DOI: https://doi.org/10.4121/uuid: d4b44881-16d7-4ada-bd09-85bce081bc84 (De Nooijer, 2017).

The Supplement related to this article is available online at https://doi.org/10.5194/bg-14-3387-2017-supplement.
Competing interests. The authors declare that they have no conflict of interest.

Acknowledgements. We would like to thank Helen de Waard for the chemical analyses. This work is supported by the Gravitation grant NESSC from the Dutch Ministry of Education, Culture and Science.

Edited by: Hiroshi Kitazato

Reviewed by: two anonymous referees

\section{References}

Allen, K. A., Hönisch, B., Eggins, S. M., Yu, J., Spero, H. J., and Elderfield, H.: Controls on Boron incorporation in cultured tests of the planktic foraminifer Orbulina universa, Earth Planet. Sc. Lett., 309, 291-301, 2011.

Allen, K. A., Hönisch, B., Eggins, S. M., and Rosenthal, Y.: Environmental controls on $\mathrm{B} / \mathrm{Ca}$ in calcite tests of the tropical planktic foraminifer species Globigerinoides ruber and Globigerinoides sacculifer, Earth Planet. Sc. Lett., 351-352, 270-280, 2012.

Babila, T. L., Rosenthal, Y., and Conte, M. H.: Evaluation of the biogeochemical controls on B / Ca of Globigerinoides ruber from the Ocean Flux Program, Bermuda, Earth Planet. Sc. Lett., 404, 67-76, 2014.

Bahr, A., Schönfeld, J., Hoffmann, J., Voigt, S., Aurahs, R., Kucera, M., Slögel, S., Jentzen, A., and Gerdes, A.: Comparison of $\mathrm{Ba} / \mathrm{Ca}$ and $\delta 180$ water as freshwater proxies: A multi-species core-top study on planktonic foraminifera from the vicinity of the Orinoco River mouth, Earth Planet. Sc. Lett., 383, 45-57, 2013.

Bentov, S. and Erez, J.: Impact of biomineralization processes on the $\mathrm{Mg}$ content of foraminiferal shells: A biological perspective, Geochem. Geophy. Geosy., 7, Q01P08, https://doi.org/10.1029/2005GC001015, 2006.

Bian, N. and Martin, P. A.: Investigating the fidelity of $\mathrm{Mg} / \mathrm{Ca}$ and other element data from reductively cleaned planktonic foraminifera, Paleoceanography 25, PA2215, https://doi.org/10.1029/2009PA001796, 2010.

Boyle, E. A.: Cadmium, zinc, copper and barium in foraminifera tests, Earth Planet. Sc. Lett., 53, 11-35, 1981.

Bradshaw, A. L., Brewer, P. G., Shafer, D. K., and Williams, R. T.: Measurements of total carbon dioxide and alkalinity by potentiometric titration in the GEOSECS program, Earth Planet. Sc. Lett., 55, 99-115, 1981.

Broecker, W. S. and Peng T.-H.: Tracers in the Sea, Eldigo Press, Lamont-Doherty Geological Observatory, Palisades, New York, USA, 690 pp., 1982.

Bryan, S. P. and Marchitto, T. M.: Mg/Ca-temperature proxy in benthic foraminifera: New calibrations from the Florida Straits and a hypothesis regarding $\mathrm{Mg} / \mathrm{Li}$, Paleoceonography, 23, PA2220, https://doi.org/10.1029/2007PA001553, 2008.

Chan, L. H., Drummond, D., Edmond, J. M., and Grant, B.: On the barium data from the Atlantic GEOSECS expedition, Deep-Sea Res., 24, 613-649, 1977.

Dawber, C. F. and Tripati, A.: Relationships between bottom water carbonate saturation and element / Ca ratios in coretop sam- 
ples of the benthic foraminifera Oridorsalis umbonatus, Biogeosciences, 9, 3029-3045, https://doi.org/10.5194/bg-9-30292012, 2012.

Delaney, M. L., Bé, A. W. H., and Boyle E. A.: Li, Sr, Mg and Na in foraminiferal clacite shells from laboratory culture, sediment traps, and sediment cores, Geochim. Cosmochim. Ac., 49, 13271341, 1985.

De Nooijer, L. J.: Data presented in the paper "Ba incorporation in benthic foraminifera", 4TU, https://doi.org/10.4121/uuid: d4b44881-16d7-4ada-bd09-85bce081bc84, 2017.

De Nooijer, L. J., Toyofuku, T., and Kitazato, H.: Foraminifera promote calcification by elevating their intracellular $\mathrm{pH}, \mathrm{P}$. Natl. Acad. Sci. USA, 106, 15374-15378, 2009.

De Nooijer, L. J., Hathorne, E. C., Reichart, G. J., Langer, G., and Bijma, J.: Variability in calcitic $\mathrm{Mg} / \mathrm{Ca}$ and $\mathrm{Sr} / \mathrm{Ca}$ ratios in clones of the benthic foraminifer Ammonia tepida, Mar. Micropaleontol., 107, 33-43, 2014a.

De Nooijer, L. J., Spero, H. J., Erez, J., Bijma, J., and Reichart, G. J.: Biomineralization in perforate foraminifera, Earth-Sci. Rev., 135, 48-58, 2014b.

Dickson, A. G. and Millero, F. J.: A comparison of the equilibrium constants for dissociation constants of carbonic acid in seawater media, Deep-Sea Res., 34, 1733-1743, 1987.

Dueñas-Bohórquez, A., Da Rocha, R., Kuroyanagi, A., Bijma, J., and Reichart, G. J.: Effect of salinity and seawater calcite saturation state on $\mathrm{Mg}$ and $\mathrm{Sr}$ incorporation in cultured planktonic foraminifera, Mar. Micropaleontol., 73, 178-189, 2009.

Dueñas-Bohórquez, A., Raitzsch, M., De Nooijer, L. J., and Reichart, G. J.: Independent impacts of calcium and carbonate ion concentration on $\mathrm{Mg}$ and $\mathrm{Sr}$ incorporation in cultured benthic foraminifera, Mar. Micropaleontol., 81, 122-130, 2011.

Eggins, S., De Deckker, P., and Marshall, J.: Mg / Ca variation in plaktonic foraminifera tests: implications for reconstructing palaeo-seawater temperature and habitat migration, Earth Planet. Sc. Lett., 212, 291-306, 2003.

Elderfield, H., Cooper, M., and Ganssen, G.: Sr / Ca in multiple species of planktonic foraminifera: Implications for reconstructions of seawater $\mathrm{Sr} / \mathrm{Ca}$, Geochem. Geophy. Geosy., 1, GC000031, https://doi.org/10.1029/1999GC000031, 2000.

Elderfield, H., Vautravers, M., and Cooper, M.: The relationship between shell size and $\mathrm{Mg} / \mathrm{Ca}, \mathrm{Sr} / \mathrm{Ca}, \delta 18 \mathrm{O}$, and $\delta 13 \mathrm{C}$ of species of planktonic foraminifera, Geochem. Geophy. Geosy., 3, GC000194, https://doi.org/10.1029/2001GC000194, 2002.

Elderfield, H., Yu, J., Anand, P., Kiefer, T., and Nyland, B.: Calibrations for benthic foraminiferal $\mathrm{Mg} / \mathrm{Ca}$ paleothermometry and the carbonate ion hypothesis, Earth Planet. Sc. Lett., 250, 633649, 2006

Erez, J.: The source of ions for biomineralization in foraminifera and their implications for paleoceanographic proxies, Rev. Mineral. Geochem., 54, 115-149, 2003.

Evans, D., Erez, J., Oron, S., and Müller, W.: Mg / Ca-temperature and seawater-test chemistry relationships in the shallow-dwelling large benthic foraminifera Operculina ammonoides, Geochim. Cosmochim. Ac., 148, 325-342, 2015.

Foster, G. L.: Seawater $\mathrm{pH}, p \mathrm{CO}_{2}$ and $\left[\mathrm{CO}_{3}^{2-}\right]$ variations in the Caribbean Sea over the last $130 \mathrm{kyr}$ : A boron isotope and B / Ca study of planktonic foraminifera, Earth Planet. Sc. Lett., 271, 254-266, 2008.
Glas, M. S., Langer, G., and Keul, N.: Calcification acidifies the microenvironment of a benthic foraminifer (Ammonia sp.), J. Exp. Mar. Biol. Ecol., 424-425, 53-58, 2012.

Gran, G.: Determination of the equivalence point in potentiometric titrations - Part II, The Analyst, 77, 661-671, 1952.

Guay, C. K. and Falkner, K. K.: Barium as a tracer of Arctic halocline and river waters, Deep-Sea Res. Part II, 44, 1543-1569, 1997.

Guay, C. K. and Falkner, K. K.: A survey of dissolved barium in the estuaries of major Arctic rivers and adjacent seas, Cont. Shelf Res., 18, 859-882, 1998.

Guillong, M., Meier, D. L., Allan, M. M., Heinrich, C. A., and Yardley, B. W. D.: SILLS: A MATLAB-based program for the reduction of laser ablation ICP-MS data of homogeneous materials and inclusions, Mineralogical Association of Canada Short Course, 40, 328-333, 2008.

Hall, J. M. and Chan, L.-H.: Li / Ca in multiple species of benthic and planktonic foraminifera: Thermocline, latitudinal, and glacial-interglacial variation, Geochim. Cosmochim. Ac., 68, 529-545, 2004a.

Hall, J. M. and Chan, L.-H.: Ba / Ca in Neogloboquadrina pachyderma as an indicator of deglacial meltwater discharge into the western Arctic Ocean, Paleoceanography, 19, PA000910, https://doi.org/10.1029/2003PA000910, 2004b.

Hanor, J. S. and Chan, L.-H.: Non-conservative behavior of barium during mixing of Mississippi River and Gulf of Mexico waters, Earth Planet. Sc. Lett., 37, 242-250, 1977.

Hatch, M. B. A., Schellenberg, S. A., and Carter, M. L.: Ba / Ca variations in the modern intertidal bean clam Donax gouldii: An upwelling proxy?, Palaeogeogr. Palaeoclim. Palaeoecol., 373, 98-107, 2013.

Hathorne, E. C., James, R. H., Savage, P., and Alard, O.: Physical and chemical characteristics of particles produced by laser $a b-$ lation of biogenic calcium carbonate, J. Anal. Atom. Spectrom., 23, 240-243, 2008.

Hathorne, E. C., James, R. H., and Lampitt, R. S.: Environmental versus biomineralization controls on the intratest variation in the trace element composition of the planktonic foraminifera G. inflata and G. scitula, Paleoceanography, 24, PA001742, https://doi.org/10.1029/2009PA001742, 2009.

Hemleben, C., Anderson, O. R., Berthold, W., and Spindler, M.: Calcification and chamber formation in foraminifera - an overview, in: Biomineralization in lower plants and animals, edited by: Leadbeater, B. S. C. and Riding, R., The Systematics Society, London, UK, 237-249, 1986.

Hendry, K. R., Rickaby, R. E. M., Meredith, M. P., and Elderfield, H.: Controls on stable isotope and trace metal uptake in Neogloboquadrina pachyderma (sinistral) from an Antarctic seaice environment, Earth Planet. Sc. Lett., 278, 67-77, 2009.

Hoffmann, J., Bahr, A., Voigt, S., Schönfeld, J., Nürnberg, D., and Rethemeyer, J.: Disentangling abrupt deglacial hydrological changes in northern South America: Insolation versus oceanic forcing, Geology, 42, 579-582, 2014.

Hönisch, B., Allen, K. A., Russell, A. D., Eggins, S. M., Bijma, J., Spero, H. J., Lea, D. W., and Yu, J.: Planktic foraminifers as recorders of seawater $\mathrm{Ba} / \mathrm{Ca}$, Mar. Micropaleontol., 79, 52-57, 2011. 
Hoppe, C. J. M., Langer, G., and Rost, B.: Emiliania huxleyi shows identical responses to elevated $p \mathrm{CO}_{2}$ in TA and DIC manipulations, J. Exp. Mar. Biol. Ecol., 406, 54-62, 2011.

Jochum, K. P., Weis, U., Stoll, B., Kuzmin, D., Yang, Q., Raczek, I., Jacob, D. E., Stracke, A., Birbaum, K., Frick, D. A., Günther, D., and Enzweiler, J.: Determiniation of reference values for NIST SRM 610-617 glasses following ISO guidelines, Geostand. Geoanal. Res., 35, 397-429, 2011.

Kaczmarek, K., Langer, G., Nehrke, G., Horn, I., Misra, S., Janse, M., and Bijma, J.: Boron incorporation in the foraminifer Amphistegina lessonii under a decoupled carbonate chemistry, Biogeosciences, 12, 1753-1763, https://doi.org/10.5194/bg-121753-2015, 2015.

Kester, D. R., Duedall, I. W., and Connors, D. N.: Preparation of artificial seawater, Limnol. Oceanogr., 12, 176-179, 1967.

Kunioka, D., Shirai, K., Takahata, N., Sano, Y., Toyofuku, T., and Ujiie, Y.: Microdistribution of $\mathrm{Mg} / \mathrm{Ca}, \mathrm{Sr} / \mathrm{Ca}$, and $\mathrm{Ba} / \mathrm{Ca}$ ratios in Pulleniatina obliquiloculata test by using a NanoSIMS: Implication for the vital effect mechanism, Geochem. Geophy. Geosy., 7, GC001280, https://doi.org/10.1029/2006GC001280, 2006.

Langer, G., Nehrke, G., Thoms, S., and Stoll, H.: Barium partitioning in coccoliths of Emiliania huxleyi, Geochim. Cosmochim. Ac., 73, 2899-2906, 2009.

Langer, G., Sadekov, A., Thoms, S., Keul, N., Nehrke, G., Mewes, A., Greaves, M., Misra, S., Reichart, G. J., De Nooijer, L. J., Bijma, J., and Elderfield, H.: Sr partitioning in the benthic foraminifera Ammonia aomoriensis and Amphistegina lessonii, Chem. Geol., 440, 306-312, 2016.

Lea, D. and Boyle, E.: Barium content of benthic foraminifera controlled by bottom-water composition, Nature, 338, 751-753, 1989.

Lea, D. W.: A trace metal perspective on the evolution of Antarctic circumpolar deepwater chemistry, Paleoceanography, 10, 733747, 1995

Lea, D. W. and Boyle, E. A.: A 210000 -year record of barium variability in the deep northwest Atlantic Ocean, Nature, 347, 269 272, 1990.

Lea, D. W. and Boyle, E. A.: Barium in planktonic foraminifera, Geochim. Cosmochim. Ac., 55, 3321-3331, 1991.

Lea, D. W. and Boyle, E. A.: Determination of carbonate-bound barium in foraminifera and corals by isotope dilution plasmamass spectrometry, Chem. Geol., 103, 73-84, 1993.

Lea, D. W. and Spero, H. J.: Experimental determination of barium uptake in shells of the planktonic foraminifera Orbulina universa at $22^{\circ} \mathrm{C}$, Geochim. Cosmochim. Ac., 56, 2673-2680, 1992.

Lea, D. W. and Spero, H. J.: Assessing the reliability of paleochemical tracers: Barium uptake in the shells of planktonic foraminifera, Paleoceanography, 9, 445-452, 1994.

Lea, D. W., Shen, G. T., and Boyle, E. A.: Coralline barium records temporal variability in equatorial Pacific upwelling, Nature, 340, 373-376, 1989.

Lear, C. H., Mawbey, E. M., and Rosenthal, Y.: Cenozoic benthic foraminiferal $\mathrm{Mg} / \mathrm{Ca}$ and $\mathrm{Li} / \mathrm{Ca}$ records: Toward unlocking temperatures and saturation states, Paleoceanography, 25, PA001880, https://doi.org/10.1029/2009PA001880, 2010.

Lee, J. J.: Algal symbiosis in larger foraminifera, Symbiosis, 42, 63-75, 2006.
Li, Y.-H. and Chan, L.-H.: Desorption of Ba and 226Ra from riverborne sediments in the Hudson Estuary, Earth Planet. Sc. Lett., 37, 242-250, 1979.

Marr, J. P., Carter, L., Bostock, H. C., Bolton, A., and Smith, E.: Southwest Pacific Ocean response to a warming world: Using $\mathrm{Mg} / \mathrm{Ca}, \mathrm{Zn} / \mathrm{Ca}$, and $\mathrm{Mn} / \mathrm{Ca}$ in foraminifera to track surface ocean water masses during the last deglaciation, Paleoceanography, 28, 347-362, 2013.

Marriott, C. S., Henderson, G. M., Crompton, R., Staubwasser, M., and Shaw, S.: Effect of mineralogy, salinity, and temperature on $\mathrm{Li} / \mathrm{Ca}$ and $\mathrm{Li}$ isotope composition of calcium carbonate, Chem. Geol., 212, 5-15, 2004.

Mehrbach, C., Culberson, C. H., Hawley, J. E., and Pytkowicz, R. N.: Measurement of the apparent dissociation constants of carbonic acid in seawater at atmospheric pressure, Limnol. Oceanogr., 18, 897-907, 1973.

Mewes, A., Langer, G., De Nooijer, L. J., Bijma, J., and Reichart, G. J.: Effect of different seawater $\mathrm{Mg}^{2+}$ concentrations on calcification in two benthic foraminifers, Mar. Micropaleontol., 113, 56-64, 2014.

Mewes, A., Langer, G., Reichart, G. J., De Nooijer, L. J., Nehrke, G., and Bijma, J.: The impact of $\mathrm{Mg}$ contents on Sr partitioning in benthic foraminifers, Chem. Geol., 412, 92-98, 2015.

Morse, J. W. and Bender, M. L.: Partition coefficients in calcite: Examination of factors influencing the validity of experimental results and their application to natural systems, Chem. Geol., 82, 265-277, 1990.

Morse, J. W., Arvidson, R. S., and Lüttge, A.: Calcium carbonate formation and dissolution, Chem. Rev., 107, 342-381, 2007.

Mucci, A. and Morse, J. W.: The incorporation of $\mathrm{Mg}^{2+}$ and $\mathrm{Sr}^{2+}$ into calcite overgrowths: influences of growth rate and solution composition, Geochim. Cosmochim. Ac., 47, 217-233, 1983.

Nehrke, G., Keul, N., Langer, G., de Nooijer, L. J., Bijma, J., and Meibom, A.: A new model for biomineralization and traceelement signatures of Foraminifera tests, Biogeosciences, 10, 6759-6767, https://doi.org/10.5194/bg-10-6759-2013, 2013.

Ni, Y., Foster, G. L., Bailey, T., Elliott, T., Schmidt, D. N., Pearson, P., Haley, B., and Coath, C.: A core top assessment of proxies for the ocean carbonate system in surface-dwelling foraminifera, Paleoceanography, 22, PA3212, https://doi.org/10.1029/2006PA001337, 2007.

Ni Flaithearta, S., Reichart, G. J., Jorissen, F. J., Fontanier, C., Rohling, E. J., Thomson, J., and De Lange, G.: Reconstructing the seafloor environment during sapropel formation using benthic foraminiferal trace metals, stable isotopes, and sediment composition, Paleoceanography, 25, PA4225, https://doi.org/10.1029/2009PA001869, 2010.

Nürnberg, D., Bijma, J., and Hemleben, C.: Assessing the reliability of magnesium in foraminiferal calcite as a proxy for water mass temperatures, Geochim. Cosmochim. Ac., 80, 803-814, 1996.

Okai, T., Suzuki, A., Kawahata, H., Terashima, S., and Imai, N.: Preparation of a New Geological Survey of Japan Geochemical Reference Material: Coral JCp-1, Geostandard. Newslett., 26, 95-99, 2002.

Pak, D. K., Lea, D. W., and Kennett, J. P.: Seasonal and interannual variation in Santa Barbara Basin water temperatures observed in sediment trap foraminiferal $\mathrm{Mg} / \mathrm{Ca}$, Geochem. Geophy. Geosy., 5, Q12008, https://doi.org/10.1029/2004GC000760, 2004. 
Pierrot, D., Lewis, E., and Wallace, D. W. R.: MS Excel program developed for $\mathrm{CO}_{2}$ system calculations. ORNL/CDIAC-105. Carbon dioxide Information Analysis Center, Oak Ridge National Laboratory, US department of Energy, Oak Ridge, Tennessee, USA, 2006.

Raitzsch, M., Hathorne, E. C., Kuhnert H., Groeneveld, J., and Bickert, T.: Modern and late Pleistocene B / Ca ratios of the benthic foraminifer Planulina wuellerstorfi determined with laser ablation ICP-MS, Geology, 39, 1039-1042, 2011.

Raja, R., Saraswati, P. K., Rogers, K., and Iwao, K.: Magnesium and strontium compositions of recent symbiont-bearing benthic foraminifera, Mar. Micropaleontol., 58, 31-44, 2005.

Reddy, M. M. and Nancollas, G. H.: The crystallization of calcium carbonate: IV. The effect of magnesium, strontium and sulfate ions, J. Crystal Growth, 35, 33-38, 1976.

Reichart, G. J., Jorissen, F., Anschutz, P., and Mason, P. R. D.: Single foraminiferal test chemistry records the marine environment, Geology, 31, 355-358, 2003.

Rubin, S. I., King, S. L., Jahnke, R. A., and Froelich, P. N.: Benthic barium and alkalinity fluxes: Is $\mathrm{Ba}$ an oceanic paleo-alkalinity proxy for glacial atmosphere $\mathrm{CO}_{2}$ ?, Geophy. Res. Lett., 30, 1885, https://doi.org/10.1029/2003GL017339, 2003.

Sadekov, A., Eggins, S. M., De Deckker, P., and Kroon, D.: Uncertainties in seawater thermometry deriving from intratest and intertest $\mathrm{Mg} / \mathrm{Ca}$ variability in Globigerinoides ruber, Paleoceanography, 23, PA0014502, https://doi.org/10.1029/2007PA001452, 2008.

Sadekov, A., Bush, F., Kerr, J., Ganeshram, R., and Elderfield, H.: $\mathrm{Mg} / \mathrm{Ca}$ composition of benthic foraminifera Miliolacea as a new tool of paleoceanography, Paleoceanography, 29, 990-1001, 2014.

Segev, E. and Erez, J.: Effect of Mg / Ca ratio in seawater on shell composition in shallow benthic foraminifera, Geochem. Geophy. Geosy., 7, GC000969, https://doi.org/10.1029/2005GC000969, 2006.

Ter Kuile, B. H. and Erez, J.: Carbon budgets for two species of benthonic symbiont-bearing foraminifera, Biol. Bull., 180, 489495, 1991

Toyofuku, T., Kitazato, H., and Kawahata, H.: Evaluation of $\mathrm{Mg} / \mathrm{Ca}$ thermometry in foraminifera: Comparison of experimental results and measurements in nature, Paleoceanography, $15,456-464,2000$.
Toyofuku, T., Suzuki, M., Suga, H., Sakai, S., Suzuki, A., Ishikawa, T., De Nooijer, L. J., Schiebel, R., Kawahata, H., and Kitazato, $\mathrm{H} .: \mathrm{Mg} / \mathrm{Ca}$ and $\delta^{18} \mathrm{O}$ in the brackish shallow-water benthic foraminifer Ammonia "beccarii”, Mar. Micropaleontol., 78, 113-120, 2011.

Toyofuku, T., Matsuo, M. Y., De Nooijer, L. J., Nagai, Y., Kawada, S., Fujita, K., Reichart, G.-J., Nomaki, H., Tsuchiya, M., Sakaguchi, H., and Kitazato, H.: Proton pumping accompanies calcification in foraminifera, Nat. Commun., 8, 14145, https://doi.org/10.1038/ncomms14145, 2017.

van Dijk, I., de Nooijer, L. J., and Reichart, G.-J.: Trends in element incorporation in hyaline and porcelaneous foraminifera as a function of $p \mathrm{CO}_{2}$, Biogeosciences, 14, 497-510, https://doi.org/10.5194/bg-14-497-2017, 2017.

Weldeab, S., Lea, D. W., Schneider, R. R., and Andersen, N.: 155000 years of west African monsoon and ocean thermal evolution, Science, 316, 1303-1307, 2007.

Weldeab, S., Lea, D. W., Oberhänsli, H., and Schneider, R. R.: Links between southwestern tropical Indian Ocean SST and precipitation over southeastern Africa over the last $17 \mathrm{kyr}$, Palaeogeogr. Palaeoclimatol. Palaeoecol., 410, 200-212, 2014.

Wilson, S. A., Koenig, A. E., and Orklid, R.: Development of microanalytical reference material (MACS-3) for LA-ICP-MS analysis of carbonate samples, Supplement, Geochim. Cosmochim. Ac., 72, A1025-A1025, 2008.

Wit, J. C., de Nooijer, L. J., Barras, C., Jorissen, F. J., and Reichart, G. J.: A reappraisal of the vital effect in cultured benthic foraminifer Bulimina marginata on $\mathrm{Mg}$ / Ca values: assessing temperature uncertainty relationships, Biogeosciences, 9, 36933704, https://doi.org/10.5194/bg-9-3693-2012, 2012.

Wit, J. C., de Nooijer, L. J., Wolthers, M., and Reichart, G. J.: A novel salinity proxy based on $\mathrm{Na}$ incorporation into foraminiferal calcite, Biogeosciences, 10, 6375-6387, https://doi.org/10.5194/bg-10-6375-2013, 2013.

Yu, J. and Elderfield, H.: Benthic foraminiferal B / Ca ratios reflect deep water carbonate saturation state, Earth Planet. Sc. Lett., 258, 73-86, 2007.

Yu, J., Day, J., Greaves, M., and Elderfield, H.: Determination of multiple element/ calcium ratios in foraminiferal calcite by quadrupole ICP-MS, Geochem. Geophy. Geosy., 6, Q08P01, https://doi.org/10.1029/2005GC000964, 2005. 